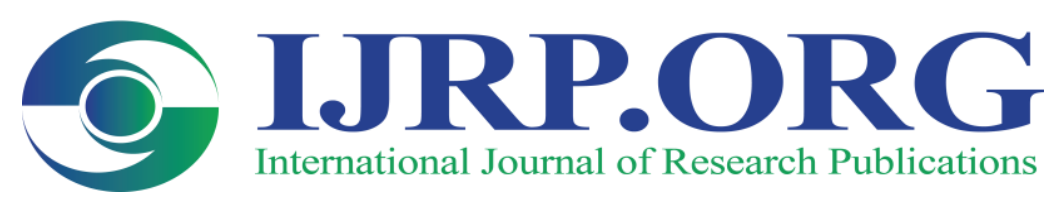

International Journal of Research Publications

\title{
Stress Management Training On Former Commercial Sex Workers At PSKW Mulya Jaya
}

\author{
Oktavia Setyawati ${ }^{\text {a }}$ Nilam Widyarini ${ }^{\text {b }}$ \\ Gunadarma University, Indonesia (setyawatiocata@gmail.com) \\ Gunadarma University, Indonesia (nilam.wid@gmail.com)
}

\begin{abstract}
Stress experienced by former commercial sex workers in line with the events and journeys of life the individual and the occurrence is unavoidable completely. Stress management training is the main orientation is to look for and face the subject matter by learning new strategies or skills in order to reduce the environmental stressors faced and perceived. The research aims to find out the sense of stress experienced in commercial sex workers. The research approach used is quantitative with one test group Pretest-Posttest design. The population and samples of this research is a former commercial sex worker in PSKW Mulya Jaya Jakarta which is identified with the stress with the number of research samples of 12 people, who are 16 years old to 37 years. Implementation of the research using pre intervention and post test methods. Data analysis techniques using Wilcoxon test method $\mathrm{Z}=-$ $2,984(\mathrm{P}<0.05)$ Means there is a significant meaningful difference between the pre-test and post-test of the influence of intervention on the decline in stress levels. It can be concluded that if there is a significant difference between the level of stress before and after the intervention and the influence of intervention that has been performed against the decline in stress levels.
\end{abstract}

(C) 2018 Published by IJRP.ORG. Selection and/or peer-review under responsibility of International Journal of Research Publications (IJRP.ORG)

Keywords: Stress, stress management training 


\section{Preliminary}

The phenomenon of prostitution or often referred to as PSK (Commercial Sex Worker) is considered to have existed for a long time along with human civilization. Its existence often poses a dilemma situation. On the one hand being a kindergartener is an unavoidable life choice to overcome the difficulties of living because of poverty. In general, the beneficiary's reaction (PM), experiencing psychiatric stress such as stress, behavior changes to depression. On the other hand, the profession of psk is a form of social pathology that goes against religious values and social rules (Susetyo \& Sudiantara, 2015).

The government is trying to solve this social problem by establishing one of them is the rehabilitation center of PSKW Mulya Jaya in Pasar Rebo area of Jakarta for commercial sex workers (PSK) who provide services and rehabilitation for commercial sex workers (PSK) and trafficking victims. Rehabilitation aims to make commercial sex workers (PSK) have skills that can be developed after they have finished rehab for 6 months and as a new, more rewarding job.

In general, individuals who experience stress will be disturbed by their life cycle and feel discomfort. Therefore, the condition of individuals experiencing stress symptoms can be seen both physically and psychologically (Sukadiyanto, 2010).

There are some problems faced by beneficiaries (PM) while in PSKW Mulya Jaya, among others feel uncomfortable with the regulations and try to escape, some who do not admit if guilty, sadly because parting with family, feel guilty about already being a commercial sex worker (PSK). The seniority, the act of bullying, to the violent acts such as beatings experienced by the PM (beneficiaries) who are still juniors.

Waters (2015) states that stress can be interpreted as a set of physiological, psychological and behavioral reactions to stimuli (good or bad). Based on the "Stress in America Survey" conducted by APA in 2014 despite high stress levels in 2013, revealed that $50 \%$ of teenagers do not feel confident about their ability to deal with their personal problems and $42 \%$ feel that they are not doing well enough to manage their stress. Stress can be tolerated coming from one intense event (e.g., the death of a loved one) in which the child has the support and resources to heal and grow from the event. Positive stress, or minor stress, is triggered by everyday adverse situations.

Cahyati \& Rustiana (2012) revealed that stress is a condition caused by transactions between individuals and the environment that give rise to a perception of the distance between the demands derived from the levers and resources in a person's biological, psychological and social systems.

In general, the reaction struck by former commercial sex workers, experiencing psychiatric stress such as stress, behavior changes to depression. Former commercial sex workers often exhibit poor behavior and relationships between individuals either former commercial sex workers or with social workers when having problems or solving problems even to quarrels between fellow former commercial sex workers.

To do so, it takes an intervention that can help a former commercial sex worker to manage the stress she is experiencing. In this study, researchers will conduct a stress management intervention program. In general, stress management interventions aim to improve an individual's ability to deal with and manage their situation or stress sources in order to lower their stress levels.

In addition to the effects of exercise on perceived stress levels, the cognitivebehavioral response of patients with depression to cope with stress and exercise effects on these variables is critical. However, until now the effects of exercise and physical activity on changes in the use rate of three problem-focused, emotion-focused, and avoidant-focused coping methods with stress have not been addressed extensively 
Methods of coping with stress can be divided into two categories: Problem focused coping which includes efforts to overcome stress and emotion-focused coping that includes trying to alleviate negative emotions caused by stressors (Folkman \& Lazarus 1985).

Researchers have hypothesized that applying stress management can lower stress levels in former commercial sex workers. Therefore, the purpose of this study is to look at the effect of applying stress management in groups to the stress levels of former commercial sex workers.

\section{Research methods}

The study was conducted at PSKW Mulya Jaya South Jakarta with a total of 12 former commercial sex workers who were identified as experiencing stress in the rehabilitation center. The study sample was conducted by random sampling of 12 people from the age of 16 to 37 years.

The approach in this study is a quantitative research approach, the type of research used is the experiment that is one test group design Pretest-Posttest. In this study, we examined stress management training.

Stress management is where individuals control or manage stress that aims to recognize the causes of stress and know the techniques of managing stress, so that people are better at mastering stress in life While, Stress is a pressure or something that feels stressful in the individual. Stress arises in line with the events and journeys of life that individuals go through and occur completely unavoidable. In general, individuals who experience stress will be disturbed by their life cycle and feel discomfort.

The data collection technique used in this study is to use stress and observation level scale. Data obtained through stress levels refers to perceived stress scale (PSS) developed by Cohen, Kamarck and Mermelstrein (1983). Perceived stress scale (PSS) is a psychological instrument that measures an individual's picture of the stress experienced in their lives. This scale consists of 10 items based on an individual's experience and perception of what is felt in his or her life namely feelings of anpredictability, feeling of unprdictability and feeling of overloaded.

The data analysis technique used in this study is the Wilcoxon Signed Rank Test using the help of statistical product and service solution (SPSS) 23.0 for Windows application.

1.1 Table Design of Intervention Activities

\begin{tabular}{clc}
\hline Pertemuan & \multicolumn{1}{c}{ Kegiatan } & \multicolumn{1}{c}{ Metode } \\
\hline \multirow{2}{*}{ First } & $\begin{array}{l}\text { Informed concert } \\
\text { Opening } \\
\text { 1. Ice breaking } \\
\text { 2. Feedback assessment results } \\
\text { 3. Understanding stress }\end{array}$ & $\begin{array}{c}\text { Discussion } \\
\text { and presentations }\end{array}$ \\
\hline \multirow{2}{*}{ Second } & $\begin{array}{l}\text { Opening } \\
\text { 1. Understand stress through film. }\end{array}$ & Discussion \\
& $\begin{array}{l}\text { 2. Close the session. } \\
\text { Emotional focused coping } \\
\text { strategy }\end{array}$ & Presentations \\
& $\begin{array}{l}\text { Practice emotionally focused } \\
\text { coping }\end{array}$ & $\begin{array}{l}\text { Relaxation } \\
\text { techniques }\end{array}$ \\
\hline Third & $\begin{array}{l}\text { Problem focused coping strategy } \\
\text { Problem focused coping practices }\end{array}$ & Presentations \\
\hline
\end{tabular}




$\begin{array}{lll}\text { Fourth } & \begin{array}{l}\text { Ice breaking } \\ \text { Program evaluation }\end{array} & \text { Questionnaire } \\ \end{array}$

\section{Results and Discussion}

Based on the results of research conducted at PSKW Mulya Jaya on 12 women former commercial sex workers to find out the stress that is in the rehabilitation center before and after being given stress management training techniques.

Table 1.2 Comparison of pre-test and post-test PSS-10 scores

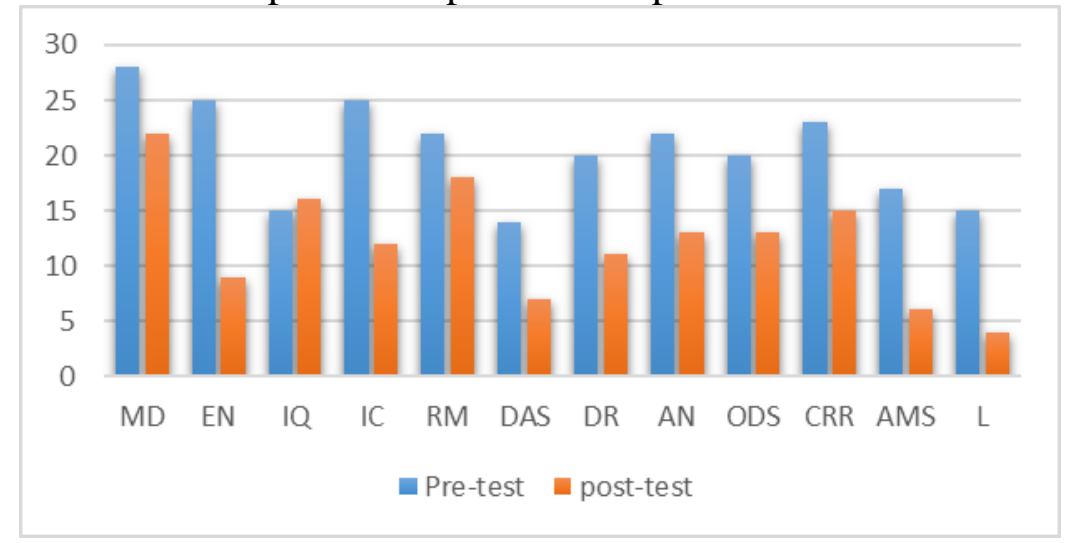

Based on pre-test and post-test results in former commercial sex workers can be seen if there is a change in stress level scores between before and after being given intervention or treatment. This intervention was conducted as many as 4 meeting sessions, within two weeks as measured using perceived stress scale (PSS-10) test equipment after being given interventions in the form of psychoedukasi regarding stress, progressive relaxation and progressive relaxation practices. After two weeks of pre-testing, researchers gave post-tests to former commercial sex workers.

Table 1.3 Statistical Description

\begin{tabular}{|c|c|c|c|c|c|}
\hline \multicolumn{6}{|c|}{ Descriptive Statistics } \\
\hline & $\mathrm{N}$ & Mean & $\begin{array}{c}\text { Std. } \\
\text { Deviation }\end{array}$ & $\underset{\mathrm{m}}{\text { Minimu }}$ & $\underset{\mathrm{m}}{\operatorname{Maximu}}$ \\
\hline Pre Test & 12 & 20.5000 & 4.50252 & 14.00 & 28.00 \\
\hline Post_test & 12 & 12.1667 & 5.20198 & 4.00 & 22.00 \\
\hline
\end{tabular}

There was a decrease in stress levels scores in former commercial sex workers. This is seen from pre-test, the average stress level score of former commercial sex workers is 20.5 which means at moderate stress levels. Then after being given an intervention or post-test, flat - the average stress level score of former commercial sex workers was 12.16 which means at mild stress levels. 
Table 1. 4 Wilcoxon Ranking Table

\begin{tabular}{|c|c|c|c|c|}
\hline \multicolumn{5}{|c|}{ Ranks } \\
\hline \multirow{7}{*}{$\begin{array}{l}\text { Post_test - Pre dan Post } \\
\text { Test }\end{array}$} & & $\mathrm{N}$ & Mean & Sum of \\
\hline & & & Rank & Ranks \\
\hline & Negative & $11^{\mathrm{a}}$ & 7.00 & 77.00 \\
\hline & Ranks & & & \\
\hline & Positive Ranks & $1^{\mathrm{b}}$ & 1.00 & 1.00 \\
\hline & Ties & $0^{c}$ & & \\
\hline & Total & 12 & & \\
\hline
\end{tabular}

a. Post_test $<$ Pre dan Post Test

b. Post_test $>$ Pre dan Post Test

c. Post_test $=$ Pre dan Post Test

From the table above seen if on negative ranks or negative differences between progressive muscle relaxation intervention results during before and after intervention is $\mathrm{n}=12$ or twelve former commercial sex workers experienced a decrease in stress levels scores. From the mean rank, it is obtained if the average decrease in pre-test and post-test stress levels is 7.00 and from the ties value of 0 means there is no equal value between pre-test and post-test.

Table 1. 5 Wilcoxon Pre-test and Post-test statistics

Post_test - Pre dan

\section{Test Statistics ${ }^{\mathrm{a}}$}

Post Test

$-2.984^{\mathrm{b}}$

.003

a. Wilcoxon Signed Ranks Test

b. Based on positive ranks.

Based on the results of calculations using SPSS 23 for windows through wilcoxon obtained data there was a significant difference between before and after the subject was given stress management training intervention $Z=-2984$ with sig: $003(\mathrm{p}<0.05)$ meaning there was a significant meaningful difference between the pre-test and post-test groups of the effect of intervention on decreased stress levels.

The results of this study are supported by research conducted by Hanum (2016) there is a significant difference between the results of the calculation of total pre-test and post-test scores $(\mathrm{t}(63)=3,260, \mathrm{p}<0.05)$. Therefore, it can be concluded that the provision of stress management intervention programs to elderly people with chronic diseases has an effect in lowering their stress levels.

\section{Conclusions and Recommendation}

\subsection{Conlusions}

Based on the results of assessments that have been made to as many as 12 beneficiaries in one unit, it is known that the problem experienced by the beneficiary is the difficulty in management of stress as well as how to solve the problem well. Most beneficiaries are very irritable and irritable, and if angry it is not uncommon for some of them to behave violently both verbally and non 
verbally, to experience physical stress such as difficulty sleeping, eating irregularly and headaches.

Based on the results of research on the effectiveness of stress management training in addressing stress in women former commercial sex workers it can be concluded that the results of most beneficiaries (PM) undergo changes in stress levels that lead to the behavior of beneficiaries becoming stable to address problems either personally or with others.

\subsection{Recommendations}

Based on the conclusions taken, it is recommended to:

1. The adviser can get closer and provide guidance with the beneficiary in order to be able to detail the problems experienced until able to provide advice according to his ability and able to lower the ego for the beneficiary. Beneficiaries are expected to be able to solve problems properly and management stress without having to behave abusively either verbally or non verbally.

2. Beneficiaries are expected to be able to resolve problems properly and deal with stress without having to behave violently either verbally or non verbally. 


\section{References}

Folkman, S. and Lazarus, R. S. (1985). If It Changes It Must Be a Process: Study of Emotion and Coping during Three Stages of a College Examination. Journal of Personality and Social Psychology, 48, 150-170.

Maghan, M. (2017). Problem Solving Style and Coping Strategies: Effects of Perceived Stress. Creative Education, 8, 2332-2351.

Waters, L. (2015). The Relationship between Strength-Based Parenting with Children's Stress Levels and Strength-Based Coping Approaches. Psychology, 6, 689-699

Soewondo, S., Menaldi, A., \& Hanum, L. (2016). Stres, Manajemen stres, dan Relaksasi Progresif. Depok : Fakultas Psikologi Universitas Indosnesia

Sukadiyanto. (2010). Stress dan Cara Menguranginya. Bandung: Angkasa.

Susetyo.B, \& Sudiantara, Y. (2015). Konsep diri pada pekerja seks komersial. Jurnal psikodimensia, Vol. 14 / 2 2015, (27 - 40) 